\title{
ADVANCED THERMAL BARRIER COATING SYSTEM DEVELOPMENT
}

CONTRACT \# DE-AC05-95OR22242

TECHNICAL PROGRESS REPORT

to the

\section{U.S. DEPARTMENT OF ENERGY}

Oak Ridge Operations Office

Oak Ridge, Tennessee

March 31, 1999

Submitted By

SIEMENS WESTINGHOUSE POWER CORPORATION

4400 Alafaya Trail

Orlando, Florida 32826-2399 


\section{DISCLAIMER}

This report was prepared as an account of work sponsored by an agency of the United States Government. Neither the United States Government nor any agency thereof, nor any of their employees, makes any warranty, express or implied, or assumes any legal liability or responsibility for the accuracy, completeness, or usefulness of any information, apparatus, product, or process disclosed, or represents that its use would not infringe privately owned rights. Reference herein to any specific commercial product, process, or service by trade name, trademark. manufacturer, or otherwise does not necessarily constitute or imply its endorsement, recommendation, or favoring by the United States Government or any agency thereof. The views and opinions of authors expressed herein do not necessarily state or reflect those of the United States Government or any agency thereof. 


\section{DISCLAIMER}

Portions of this document may be illegible in electronic image products. Images are produced from the best available original document. 


\section{Advanced Thermal Barrier Coating System Development}

\section{Program Objectives}

The objectives of the program are to provide an improved TBC system with increased temperature capability and improved reliability relative to current state of the art TBC systems. The development of such a coating system is essential to the ATS engine meeting its objectives.

The base program consists of three phases:

Phase I: Program Planning - Complete

Phase II: Development

Phase III: Selected Specimen - Bench Test

Work is being performed in Phase II and III of the program. 


\title{
Technical Progress Report
}

\section{Task II.2 Bond Coat Development - Task Complete}

No work performed during reporting period.

\section{Task II.3 Analytical Lifing Model - Task Complete}

No work performed during reporting period.

\section{Task II.4 Manufacturing Process Development - Task Complete}

No work performed during reporting period.

\author{
Task II.5 NDE, Repair and Maintenance - Task Complete
}

No work performed during reporting period.

\section{Task II.6 New TBC Concepts}

- The deposition of new TBC chemistries were continued using EB-PVD at Howmet in Whitehall, MI. These deposition runs completed the evaluation of the melt pool stability of all the chemistries that were selected from the lab scale evaluation.

- To summarize the results from the deposition runs, only one chemistry was identified to be unsuitable for deposition due to an instability in the melt pool. The details of the problems faced with that particular chemistry was reported in the last quarterly report. All the other 6 chemistries were deposited successfully at various substrate temperatures. Feed rate and the appropriate range of the gun power was identified for each of the chemistries. Microstructural characterization of the coatings clearly showed a columnar microstructure similar to that of $8 \mathrm{YSZ}$ with sub-micron inter-columnar spacing. Chemical characterization also yielded a good chemistry match between the ingot material and the coating.

- Thermal fatigue evaluation tests of the coated test pins were performed at Siemens Westinghouse, Casselberry labs. Microstructural integrity and also poor adhesion to the bond coat were primary reasons for the failure of all coatings. Observation of the failed coatings led us to believe that these failures are dependent on the respective deposition conditions. Selection of the current deposition conditions are inevitably based on the extensive past experience of deposition of 8YSZ. However, it was evident that a fundamental understanding of the deposition and growth of multi-component oxide coatings, unlike single oxides such as $\mathrm{ZrO}_{2}$, was essential for the success of new TBCs.

- A literature review of the fundamentals of the deposition and growth of multicomponent oxides allowed for identification of the important variables in order to 
improve the coating integrity. These variables are being evaluated systematically to define the magnitude of their effect on the microstructure and adhesion to the bond coat. In addition to varying deposition conditions, new microstructural designs are also being evaluated to overcome the above mentioned failures.

- Upon identification of the appropriate conditions with the new deposition conditions, coatings will be deposited on the test pins by the end of April, 1999. These test pins will then be evaluated for thermal fatigue life by the end of May allowing for definition of the future direction of the new TBC development program.

- New TBC concepts were identified in the last quarter and based on successful laboratory results, specimens for Waltz Mill high heat flux rig were coated. These samples are expected to be tested by the end of May, 1999.

\section{III.6 Blade and Vane TBC Monitor - Feasibility Study}

- Off-line testing of the blade TBC monitor was performed during the reporting period. The PC based hardware package for interfacing between Siemens Westinghouse combustion turbine and the TBC monitor provided the necessary synchronization, timing, delay and sequencing required to image thermal barrier coating spallation. Preparations are being made for an on-line demonstration at a commercial facility following a successful test. 